\title{
CHANGES OF ATMOSPHERIC METHANE CONCENTRATION PARALLEL TO CLIMATIC CHANGES
}

\author{
(Abstract) \\ by \\ B. Stauffer, H. Oeschger and J. Schwander \\ (Physikalisches Institut, Universität Bern, Sidlerstrasse 5, CH-3012 Bern, Switzerland)
}

\begin{abstract}
Measurements on ice-core samples showed that atmospheric methane concentration changed with the large climatic cycles during the last two glaciations (Stauffer and others, 1988; Raynaud and others, 1988). The methane concentration is lower in cold periods and higher in warm periods. In this paper we discuss the results of $\mathrm{CH}_{4}$ measurements of samples from periods of minor climatic change, like the climatic optimum 8000 years B.P. and the Younger Dryas period about 10000 to 11000 years B.P.. The data are interpreted in terms of the present understanding of methane sources and sinks.
\end{abstract}

\section{REFERENCES}

Raynaud, D., J. Chappelaz, J.M. Barnola, Y.S. Korotkevich and C. Lorius. 1988. Climatic and $\mathrm{CH}_{4}$ cycle implications of glacial-interglacial $\mathrm{CH}_{4}$ change in the Vostok ice core. Nature, 333(6174), 655-657.

Stauffer, B., E. Lochbronner, H. Oeschger, and J. Schwander. 1988. Methane concentration in the glacial atmosphere was only half that of the preindustrial Holocene. Nature, 332(6167), 812-814.

\section{HOLOCENE PALEOENVIRONMENTAL RECONSTRUCTION FROM DEEP GROUND TEMPERATURES, CANADIAN ARCTIC ARCHIPELAGO: A COMPARISON WITH CLIMATIC INFERENCES FROM THE $\delta^{18} 0$ RECORD OF ICE CORES}

\author{
(Abstract) \\ by \\ Alan E. Taylor \\ (Permafrost Research Section, Geophysics and Terrain Sciences Branch, Geological Survey of Canada, \\ 1 Observatory Crescent, Ottawa, Ontario K1A OY3, Canada)
}

The $\delta^{18} \mathrm{O}$ record from ice cores serves as a proxy paleoclimatic temperature record, through the association of isotopic ratio to air temperatures at time of precipitation. Climatic change may be preserved also as a signal in ground temperatures, not as a proxy indicator of past climate but as a direct consequence of the effect of past air temperature variations and associated physical processes at the ground surface. In the Canadian Arctic Archipelago, $\delta^{18} \mathrm{O}$ records are available from the Devon and Agassiz ice caps, and precision ground temperatures to depths of up to $1000 \mathrm{~m}$ are available from 40 petroleum exploration wells, about one third of which are suitable for paleoenvironmental reconstruction. There is an opportunity to compare these two methods of looking at the paleoenvironment, and to show how complementary they are to each other.

Geothermal analysis is predicated on the fundamental hypothesis that the terrestrial heat flow, which arises largely from the decay of radioactive elements within the crust, does not vary measurably in the upper few $\mathrm{km}$. But at many wells, the heat flow, calculated as the product of the measured temperature gradient and rock thermal conductivity, does vary systematically with depth in the well. While more random variations may be attributed to measurement errors, and corrections may be made for such known effects as local topography, the residual coherent "long wavelength" variation may be ascribed to effects arising from climate change.

Can we, then, determine whether a particular temperature history is consistent with the geothermal record, or ideally, invert the geothermal data to reveal a record of past surface temperatures? Attempts with varying success at paleoclimatic reconstruction from ground temperatures have been reported in the literature (e.g. Lane, 1923; Hotchkiss and Ingersoll, 1934; Birch, 1948; Cermak, 1971; Vasseur and others, 1983; Lachenbruch and others, 1986) and from temperature profiles in ice sheets (e.g. Paterson, 1968; Weertman, 1968; Budd and Young, 1982).

In this study, standard techniques in geothermics (e.g. Jaeger, 1965) have been used (1) to show the effect of any hypothesized surface paleotemperature model upon subsurface temperatures, or (2) on the hypothesis that the variation in heat flow is attributed to paleoclimatic effects, to derive a surface temperature model at each well that minimizes the 
variation in a statistical sense. The resolution of the method and limitations in our measured temperature and rock thermal conductivity data restrict the application of the second method to the past few hundred to one thousand years. The paper considers the first approach for the period $1 \mathrm{ka}-10 \mathrm{ka}$ B.P. at about a dozen wells and gives an example of the second approach at a well west of the Agassiz Ice Cap.

Aproach (1). In studying the Devon Island ice core, Fisher and Koerner (1979) present a detailed record of the mean annual air temperature at the site throughout the Holocene, based on the $\delta^{18} \mathrm{O}$ record. A simplified time-temperature model of this record is applied to the ground temperature data set for the period $1 \mathrm{ka}-10 \mathrm{ka}$ B.P. Although the effect on the ground temperatures is only subtly perceptible, the model has the effect of reducing the apparent climatically-related curvature in the data, as reflected in an improvement in the standard deviation in the calculated heat flow profile by $5 \%$ to $30 \%$. Hence, the geothermal record provides quantitative support for Holocene climatic information derived from the ice core record.

Approach (2). This inversion technique is analogous to Paterson's (1968) reconstruction of the surface temperature during the past century from a temperature profile taken in the small Meighen Ice Cap, Arctic Canada. A unique model is not obtained; rather, a small set of possible surface temperature variations consistent with the deeper subsurface temperatures is produced. Such modelling suggests that subsurface temperatures at a well $180 \mathrm{~km}$ west of the Agassiz Ice Cap are consistent with ground surface temperatures some $4-6 \mathrm{~K}$ lower at the well during the Little Ice Age; this is considerably more severe than the mean annual air temperatures projected from the $\delta^{18} \mathrm{O}$ record at Agassiz. It is possible that the large increase in ground surface temperature at the wellsite since the Little Ice Age may be attributed to some climatically-related phenomena such as increased incidence of snow cover coherent with the changing climate. A well on Devon Island is not deep enough for a comparison to that ice cap.

The oxygen isotope data provide a valuable estimate of Holocene climate with which to correct ground temperature data for terrestrial heat flow, or other studies. However, examination of the signal of more recent events suggests that ground temperatures may be considerably modified by associated transient phenomena such as snow cover, vegetation, etc. Hence, one would expect that such a Holocene correction might either understate or overstate the actual experience of the ground surface at a site.

\section{REFERENCES}

Birch, F. 1948. The effects of Pleistocene climatic variations upon geothermal gradients. An. J. Sci., 246, 729-760.

Budd, W.F. and N.W. Young. 1983. Analysis of temperature, isotope and total gas content profiles: application of modelling techniques to measured profiles of temperatures and isotopes. In Robin, G. de Q., ed. The climate record in polar ice sheets. Cambridge, Cambridge University Press, 150-177.

Cermak, V. 1971. Underground temperature and inferred climatic temperature of the past millennium. Palaeogeogr., palaeoclim., palaeoecol., 10, 1-19.

Hotchkiss, W.O. and L.R. Ingersoll. 1934. Postglacial time calculations from recent geothermal measurements in the Calumet copper mines. J. Geol., 42, 113-122.

Jaeger, J.C. 1965. Application of the theory of heat conduction to geothermal measurements. Chapter 2 in Lee, W.H.K., ed. Terrestrial heat flow. (Geophysical monograph series no. 8, American Geophysical Union) 7-23.

Lachenbruch, A.H. and B.V. Marshall. 1986. Changing climate: geothermal evidence from permafrost in the Alaskan Arctic. Science, 234, 689-696.

Lane, A.C. 1923. Geotherms of Lake Superior country. Bull Geol. Soc. Am., 34, 703-720.

Paterson, W.S.B. 1968. A temperature profile through the Meighen Ice Cap, Arctic Canada. IUGG-IASH General Assembly of Bern, Commission of Snow and Ice 1967. (Publ. no. 79 de l'Association Internationale d'Hydrologie Scientifique, Gentbrugge, Belgium), 440-449.

Paterson, W.S.B., and 7 others. 1977. An oxygen-isotope climatic record from the Devon Island ice cap, Arctic Canada. Nature, 266, 508-511.

Vasseur, G., Ph. Bernard, J. Van de Meulebrouck, Y. Kast, and J. Jolivet. 1983. Holocene paleotemperatures deduced from geothermal measurements. Palaeogeogr., palaeoclim., palaeoecol., 43, 237-259.

Weertman, J. 1968. Comparison between measured and theoretical temperature profiles of the Camp Century, Greenland, borehole. J. Geophys. Res., 73, 2691-2700.

\title{
SATELLITE AND OCEANOGRAPHIC OBSERVATIONS OF LARGE ICE-EDGE EDDIES IN THE KURIL BASIN REGION OF THE OKHOTSK SEA
}

\section{(Abstract)}

\author{
by \\ Masaaki Wakatsuchi, \\ (Institute of Low Temperature Science, Hokkaido University, Sapporo 060, Japan)
}

Seelye Martin and Esther Munoz

(School of Oceanography WB-10, University of Washington, Seattle, WA 98195, U.S.A.)

We examined the behavior of the sea ice in the Okhotsk Sea which formed over the deep Kuril Basin during the period 1978-82. When ice extended over the basin, we observed the formation of large eddies with diameters of order $200 \mathrm{~km}$. We determined the size and duration of these eddies through use of the $37 \mathrm{GHz}$ channel on the Nimbus 7 Scanning Multichannel Microwave Radiometer, and with the visible channel on the geostationary Himawari satellite. Within the ice cover, the satellite data show that these eddies produced open-water regions which persisted for $4-6$ weeks, and that the eddies recurred year after year, even though their relative position changed. Comparison of eddy positions determined from satellite data with oceanographic positions shows that the oceanography drives the eddies. An estimate of heat loss from these eddies shows that the role of the ocean eddies is to keep the region ice-free until heat loss approaches zero, so that fluxes over the eddies primarily cool the water column without adding salt. Then as the atmosphere begins to warm in spring, the eddies tend to become ice-covered, so that melt water is introduced to their surface. Examination of the oceanography shows that the early 